\title{
KEMAMPUAN KOMUNIKASI MATEMATIS MAHASISWA CALON GURU DALAM MENYELESAIKAN MASALAH MATEMATIKA DITINJAU DARI TIPE KEPRIBADIAN
}

\author{
Arien Sayang ${ }^{1}$, Theresia Laurens ${ }^{2}$, Anderson L. Palinussa ${ }^{3}$ \\ 1,2,3Program Studi Magister Pendidikan Matematika, Pascasarjana, Universitas Pattimura \\ Jalan Ir. M. Putuhena, Kampus Unpatti, Poka, Ambon, Indonesia \\ e-mail: 1sayangarien@gmail.com
}

\begin{abstract}
Abstrak
Penelitian ini bertujuan untuk mendeskripsikan kemampuan komunikasi matematis mahasiswa calon guru dalam meyelesaikan masalah matematika ditinjau dari tipe kepribadian (artisan, idealist, guardian, dan rational). Penelitian ini termasuk jenis penelitian eksploratif yang bersifat kualitatif. Subjek yang digunakan dalam penelitian ini adalah mahasiswa Program Studi Pendidikan Matematika semester 4 yang terdiri dari 1 mahasiswa untuk masing-masing tipe kepribadian artisan (SA), idealist (SI), guardian (SG), dan rational (SR). Pemilihan subjek penelitian berdasarkan teknik pengambilan stratified sampling kemudian purposive sampling. Teknik analisis data mengacu pada konsep Miles dan Huberman yang meliputi reduksi data, penyajian data, dan penarikan kesimpulan. Teknik keabsahan data menggunakan triangulasi metode dan triangulasi sumber. Hasil penelitian memberikan kesimpulan: 1) SA memenuhi tiga indikator yakni mampu menuliskan informasi yang diketahui dan ditanyakan, membuat gambar, dan melakukan perhitungan; 2) SI memenuhi empat indikator yakni mampu menuliskan informasi yang diketahui dan ditanyakan, membuat gambar, melakukan perhitungan, dan menerapkan simbol dan aturan matematis sesuai dengan permasalahan yang dimaksudkan; 3) SG memenuhi tiga indikator yakni mampu membuat gambar, melakukan perhitungan, dan menuliskan simbol dan aturan matematis; 4) SR memenuhi dua indikator yakni mampu menuliskan informasi yang diketahui dan ditanyakan, dan melakukan perhitungan, sedangkan pada indikator dua lainnya yaitu membuat gambar dan menerapkan simbol matematis.
\end{abstract}

Kata Kunci: komunikasi matematis, menyelesaikan masalah, tipe kepribadian

\section{MATHEMATICAL COMMUNICATION SKILLS OF PROSPECTIVE TEACHER STUDENTS IN SOLVING MATHEMATICAL PROBLEMS IN TERMS OF PERSONALITY TYPES}

\begin{abstract}
This study aims to describe the mathematical communication skills of prospective teacher students in solving mathematical problems Evaluated from Personality Types (artisan, idealist, guardian, dan rational). This research is a kind of qualitative exploratory research. The subjects used in this study were students of the 4th semester Mathematics Education consisting of 1 student for each type of artisan personality (SA), idealist personality (SI), guardian personality (SG), and rational personality (SR). The selection of research subjects is based on stratified sampling technique then purposive sampling. Data analysis techniques refer to the concept of Miles and Huberman which includes data reduction, data presentation, and drawing conclusions. The data validity technique uses the method triangulation and source triangulation. The results of the research show that: 1) SA meets three indicators namely being able to write information that is known and asked, draw pictures, and do calculations; 2) SI fulfills four indicators which are able to write information that is known and asked, draw pictures, do calculations, and apply mathematical symbols and rules in accordance with the intended problem; 3) SG fulfills three indicators namely being able to make drawings, do calculations, and write symbols and mathematical
\end{abstract}


rules; 4) SR fulfills two indicators namely being able to write information that is known and asked, and doing calculations..

Keywords: mathematical communication, problem solving, personality type

\section{Pendahuluan}

Pendidikan merupakan wadah bagi suatu negara untuk dapat menghasilkan sumber daya manusia yang handal. Dewasa ini, paradigma pendidikan di Indonesia semakin berkembang. Hal ini ditandai dengan perubahan kurikulum yang diterapkan mulai dari tingkat Sekolah Dasar hingga Perguruan Tinggi. Pada paradigma lama, guru/dosen bertugas mentransfer ilmu pengetahuan (transfer of knowledge) kepada para siswa/mahasiswa, sedangkan siswa/mahasiswa hanya pasif menerima ilmu yang ditransfer oleh guru/dosennya tersebut. Namun, pada paradigma baru, guru/dosen hanya berperan sebagai manajer pada proses pembelajaran/perkuliahan dan mendorong siswa/mahasiswa agar aktif berkomunikasi dalam belajarnya (stimulation of learning) (Qohar, 2011).

Komunikasi merupakan sarana untuk terjalinnya hubungan antar seseorang dengan orang lain. Dalam dunia pendidikan matematika, khususnya pada mahasiswa perguruan tinggi dibidang keguruan, kemampuan komunikasi merupakan suatu kemampuan dasar yang esensial dan wajib dimiliki untuk mendukung tugas dan kewajibannya sebagai calon guru. Hal ini dikarenakan kemampuan guru dalam berkomunikasi merupakan salah satu faktor yang mempengaruhi kegiatan belajar siswa di sekolah (Dewi, 2014; Mulyasa, 2005). Sehingga mahasiswa yang dipersiapkan sebagai calon guru, diharapkan nantinya dapat mengomunikasikan konsep, struktur, teorema, atau rumus, serta teknik penyelesaian masalah matematis kepada siswa secara tepat. Dengan demikian siswa juga dapat memahami serta menerapkannya, dan dapat menyelesaikan masalah matematis secara tepat.

Komunikasi dapat terjalin antar mahasiswa dengan dosen, mahasiswa dengan mahasiswa, dan mahasiswa dengan sumber belajarnya berupa buku maupun internet. Sudrajat (Ramdani, 2012) berpendapat bahwa ketika seorang mahasiswa memperoleh informasi berupa konsep matematika yang diberikan dosen maupun yang diperolehnya dari bacaan, maka saat itu terjadi transformasi informasi matematika dari sumber kepada mahasiswa tersebut. Selanjutnya mahasiswa tersebut memberikan respon berdasarkan interpretasinya terhadap informasi itu, sehingga terjadilah proses komunikasi matematis.

Komunikasi matematis merupakan cara mengungkapkan ide-ide matematis secara lisan, tulisan, gambar, diagram, menggunakan benda, menyajikan dalam bentuk aljabar, atau menggunakan simbol matematika (NCTM, 2000). Schoen, Bean, dan Zibarth (Nuraeni \& Luritawaty, 2016; Sumarmo dkk, 2018) berpendapat bahwa komunikasi matematis adalah kemampuan: menjelaskan algoritma dan cara unik menyelesaikan pemecahan masalah; mengonstruksi dan menjelaskan sajian fenomena dunia nyata secara grafik, kata-kata dan kalimat, persamaan, tabel, dan sajian secara fisik; memberikan dugaan tentang gambar-gambar geometri. Kemampuan komunikasi matematis dapat dibedakan atas kemampuan komunikasi matematis lisan dan kemampuan komunikasi matematis tulisan. Menurut Hodiyanto (2017) kemampuan komunikasi matematis lisan dapat berupa berbicara, mendengarkan, berdiskusi, maupun bertukar pendapat. Sedangkan kemampuan komunikasi matematis tulisan dapat berupa ungkapan ide matematika melalui gambar/grafik, tabel, persamaan, ataupun dengan bahasa peserta didik.

Menurut NCTM (2000) komunikasi matematis menekankan pada kemampuan peserta didik dalam hal: (1) mengatur dan mengkonsolidasikan pemikiran pemikiran matematis (mathematical thinking) mereka melaui komunikasi, (2) Mengkomunikasikan mathematical thinking mereka secara koheren (tersusun secara logis) dan jelas kepada temantemannya, guru dan orang lain, (3) menganalisis dan mengevaluasi pemikiran matematis (mathematical thinking) dan stategi yang dipakai orang lain, dan (4) menggunakan bahasa matematika untuk mengekspresikan ide-ide matematika secara benar. Sementara itu, Dewi (2014) menyebutkan untuk mengetahui komunikasi matematika diperlukan indikator keakuratan yang dapat menentukan apakah informasi yang diberikan akurat atau tidak. Indikator tersebut yakni: (1)Menuliskan hal-hal yang relevan dengan permasalahan, (2) Menuliskan rumus atau syarat-syarat sesuai dengan penjelasan pada kriteria (1), (3) 
Melakukan hitungan sesuai dengan rumus yang digunakan pada bahagian (2) dan setiap langkah perhitungan tidak ada yang salah, (4) Menggambar grafik sesuai dengan perhitungan yang dilakukan pada bahagian (3).

Di dalam kegiatan perkuliahan sering ditemui: (1) sebagian mahasiswa dapat mengomunikasikan hasil pemikirannya namun sebagian yang lain kurang demikian, (2) mahasiswa yang memiliki kemampuan matematis tinggi tetapi tidak mampu bahkan sulit dalam mengomunikasikan apa yang dipahami di depan teman maupun dosen, begitupun sebaliknya, dan (3) mahasiswa yang hanya mampu mengomunikasikan ide matematisnya secara lisan atau tulisan. Hal ini dikarenakan adanya perbedaan kemampuan setiap mahasiswa untuk melakukan komunikasi. Menurut Armiati (2009) perbedaan kemampuan komunikasi tiap individu dipengaruhi oleh kecerdasan emosi seseorang. Sedangkan menurut Jung (Mufarrihah dkk, 2016; Librianti, 2018) perbedaan kepribadian seseorang akan mempengaruhi bagaimana seseorang tersebut dalam menerima, mengolah dan menyampaikan informasi kepada orang lain. Dengan demikian, dapat dikatakan bahwa perbedaan kepribadian oleh setiap mahasiswa merupakan salah satu faktor yang mempengaruhi tingkah laku mahasiswa itu sendiri dalam hal berkomunikasi.

Pervin (Utaminingsih \& Setyabudi, 2012; Khamidah \& Suherman, 2016) mengemukakan bahwa kepribadian dapat diartikan sebagai karakteristik individu yang merupakan pola yang cenderung konsisten (tetap) mengenai perasaan, pikiran dan perilaku. Berpangkal pada kenyataan bahwa kepribadian manusia sangat beragam, maka segolongan ahli berusaha menggolonggolongkan manusia ke dalam tipe-tipe berdasarkan sifat-sifat tertentu, dengan alasan bahwa cara itulah yang paling efektif untuk mengenal sesama manusia dengan baik. David Keirsey (1998), seorang ahli bidang psikologi dari California State University dalam bukunya yang berjudul "Please Understand Me II", menggolongkan tipe kepribadian menjadi 4, yaitu: Artisan, Idealist, Guardian, dan Rational (Librianti, 2018; Maya, 2018; Masrukan et al., 2015; Aziz, Kusmayadi, \& Sujadi, 20 14; Hidayatulloh, Usodo, \& Riyadi, 2013; Dewiyani, 2009). Penggolongan yang dilakukan oleh Keirsey berdasarkan pemikiran bahwa perbedaan nyata yang dapat dilihat dari seseorang adalah tingkah laku (behaviour) (Panjaitan, 2015). Tingkah laku dari seseorang merupakan cerminan hal yang nampak dari apa yang dipikirkan dan dirasakan oleh orang tersebut. Jadi, implikasi dari pernyataan ini adalah jika seseorang ingin mengetahui hal yang dipikirkan oleh orang lain, dapat dilihat melalui tingkah lakunya. Keirsey menggolongkan cara berkomunikasi baik lisan maupun tulisan menjadi dua kategori, yaitu konkret (concrete) dan abstrak. Tipe guardian dan artisan merupakan komunikator konkret, sedangkan Rational dan Idealist merupakan komunikator abstrak. Komunikator konkret lebih menyukai berbicara dan menulis tentang realitas, sedangkan komunikator abstrak lebih menyukai berbicara dan menulis tentang ide-ide. Komunikator konkret menyukai fakta, angka, bukti, sedangkan komunikator abstrak menyukai teori dan hipotesis. Komunikator konkret berbicara dan menulis secara detail, spesifik, empiris, dan faktual, sedangkan komunikator abstrak secara skematik, umum, teoritis, dan fiksi (Masrukan, 2015; Librianti, 2018).

Berdasarkan pemaparan di atas, maka dalam penelitian ini, untuk mengetahui kemampuan komunikasi matematis mahasiswa tulis mahasiswa dalam kaitannya dengan kepribadian, tingkah laku yang akan dilihat adalah respon mahasiswa yang berupa hasil pekerjaan secara tulisan, berdasarkan interpretasinya terhadap masalah matematika yang diberikan. Indikator kemampuan komunikasi matematis tulis yang digunakan pada penelitian ini yaitu: (1) menuliskan hal-hal yang relevan dengan masalah, (2) membuat gambar yang relevan dengan masalah, (3) melakukan perhitungan, dan (4) menuliskan simbol dan aturan matematika. Masalah matematika yang digunakan dalam penelitian ini adalah masalah penerapan integral tentu, dengan menggunakan tahapan pemecahan masalah oleh Polya (Yuwono, 2010): memahami masalah, merencanakan pemecahan masalah, melaksanakan rencana, dan memeriksa kembali. Hal ini agar kemampuan komunikasi matematis mahasiswa dapat diungkap dan dideskripsikan secara mendalam dan runtut.

Terdapat beberapa penelitian terdahulu yang telah mencoba untuk melihat kaitan antara komunikasi matematis dengan tipe kepribadian diantaranya yaitu penelitian yang dilakukan oleh Mufarrihah dkk (2016), Penelitian yang telah dilakukan oleh Librianti (2018) yang menyatakan bahwa aspek-aspek untuk mengetahui proses komunikasi matematis siswa dalam menyelesaikan masalah terbuka ditinjau dari kepribadian Keirsey, yaitu dilihat dari aspek komunikasi simbolik, logis, dan verbal siswa, dan penelitian oleh Masrukan dkk (2015). Dari uraian tersebut, maka peneliti tertarik untuk melakukan penelitian dengan judul "Kemampuan Komunikasi Matematis Mahasiswa Calon Guru 
dalam Menyelesaikan Masalah Matematika Ditinjau dari Tipe Kepribadian.”

\section{Metode Penelitian}

Penelitian ini termasuk jenis penelitian eksploratif yang bersifat kualitatif. Dikatakan eksploratif karena penelitian ini ingin mengeksplorasi kemampuan komunikasi matematis mahasiswa calon guru dalam menyelesaikan soal integral tentu berdasarkan tipe kepribadiannya. Penelitian ini dikatakan bersifat kualitatif karena data utama tentang kemampuan komunikasi matematis mahasiswa berupa katakata tertulis atau transkrip komunikasi lisan.

Penelitian ini dilaksanakan pada mahasiswa Program Studi Pendidikan Matematika semester 4, yang telah lulus mata kuliah kalkulus integral. Subjek yang digunakan dalam penelitian ini adalah 4 orang mahasiswa yang terdiri dari 1 mahasiswa untuk masing-masing tipe kepribadian artisan (SA), idealist (SI), guardian (SG), dan rational (SR). Pemilihan subjek penelitian berdasarkan teknik pengambilan stratified sampling kemudian purposive sampling. Teknik pengambilan stratified sampling, yaitu mahasiswa diberi angket penggolongan tipe kepribadian Keirsey untuk kemudian digolongkan ke dalam kelompok tipe artisan, tipe idealist, tipe guardian, dan tipe rational. Dalam penggolongan tipe kepribadian dari 65 mahasiswa, persentase yang diperoleh untuk mahasiswa yang bertipe kepribadian artisan yaitu $10,77 \%$, mahasiswa yang bertipe kepribadian idealist yaitu $47.69 \%$, mahasiswa yang bertipe kepribadian guardian yaitu $13,85 \%$, dan mahasiswa yang bertipe kepribadian rational yaitu $27,69 \%$. Selanjutnya dengan teknik pengambilan purposive sampling, yaitu dengan mempertimbangkan (1) hasil tes kepribadian mahasiswa dengan kecenderungan tertinggi pada satu tipe tertentu (Dewiyani, 2009), (2) aktif dalam perkuliahan, (3) dapat mengemukakan pendapat/jalan pikirannya secara lisan maupun tulisan, dan (4) hasil tes pemecahan masalah.

Instrumen utama dalam penelitian ini adalah peneliti sendiri, dengan instrumen bantunya yaitu tes pemecahan masalah dan pedoman wawancara. Pengumpulan data dilakukan dengan tes dan wawancara. Melalui teknik tes dan wawancara, diperoleh data komunikasi matematis secara tulisan dan lisan, yang dapat dilihat melalui jawaban mahasiswa pada lembar jawaban dan transkrip wawancara. Selanjutnya, jawaban mahasiswa dianalisis menggunakan konsep Miles dan Huberman (Sugiyono, 2013: 99), yaitu dengan cara mereduksi data terlebih dahulu, kemudian hasil reduksi disajikan dalam bentuk deskripsi sehingga dapat dengan mudah untuk diperoleh kesimpulan. Data yang diperoleh dianalisis berdasarkan indikator komunikasi matematis tulis yaitu: (1) menuliskan hal-hal yang relevan dengan masalah, (2) membuat gambar yang relevan dengan masalah, (3) melakukan perhitungan, dan (4) menuliskan simbol dan aturan matematika.Uji kredibilitas data atau kepercayan terhadap data dilakukan dengan triangulasi metode, yaitu dengan membandingkan data hasil tes tulisan dengan hasil wawancara.

\section{Hasil dan Pembahasan}

Ketika diberi soal, terlebih dahulu peneliti mengutamakan subjek sedang dalam kondisi prima, tanpa tekanan dan keterpaksaan, serta diusahakan wawancara dilakukan sesantai mungkin. Peneliti juga menyesuaikan tempat dan waktu yang digunakan dengan keadaan subjek pada waktu senggang agar tidak mengganggu aktivitas perkuliahan maupun di luar aktivitas perkuliahan. Berikut adalah pembahasan tentang kemampuan komunikasi matematis tulis subjek dalam menyelesaikan masalah penerapan integral tentu ditinjau dari tipe kepribadian.

\subsection{Kemampuan Komunikasi Subjek SA Dalam Menyelesaikan Masalah Penerapan Integral Tentu Ditinjau Dari Tipe Kepribadian Artisan}

Dari hasil analisis terhadap hasil pekerjaan dan hasil wawancara mahasiswa dengan tipe kepribadian ini, pada indikator komunikasi matematis yang pertama yaitu menuliskan hal-hal yang relevan dengan permasalahan, subjek mampu menuliskan informasi-informasi yang diketahui dan ditanyakan sesuai dengan soal yang diberikan secara singkat dan jelas. Hal ini diperjelas dengan hasil wawancara yang mana subjek mampu menjelaskan informasi yang diketahui maupun yang ditanyakan secara singkat dan jelas. Hal ini berarti mahasiswa tersebut telah mampu memahami isi dari permasalahan yang diberikan. Kemampuan tersebut sangat penting kaitannya dalam pemecahan masalah. Hal tersebut sesuai dengan National Council of Teacher of Mathematics (NCTM) (2000) yang mengungkapkan bahwa ketika mahasiswa diberikan tantangan untuk mengkomunikasikan hasil dari proses berpikirnya secara lisan maupun tulisan, mereka akan belajar untuk menjelaskan, meyakinkan dan tepat dalam menggunakan bahasa matematika. 
Selain mampu menuliskan informasi yang diketahui maupun ditanyakan dalam soal dengan benar, SA juga mampu menuliskan dan menerapkan formula yang sesuai untuk menyelesaikan masalah. Menurut Keirsey (Librianti, 2018), seseorang yang memiliki tipe kepribadian artisan dalam meyelesaikan masalah termasuk dalam kategori utilitarian, yang mana mereka akan memilih cara paling efektif menurut mereka. Hal ini terlihat dari upaya subjek untuk mencari informasi yang belum lengkap untuk menggambar grafik yang diminta, dengan menerapkan formula yang menurutnya paling efektif.

Selanjutnya, pada indikator komunikasi matematis kedua, SA mampu membuat gambar yang relevan dengan permasalahan. Gambar yang dibuat berupa kurva pada bidang kartesius yang disesuaikan dengan informasi-informasi yang diketahui. Kemampuan SA dalam membuat gambar yang relevan dengan permasalahan ini menunjukkan bahwa SA mampu mengomunikasikan ide ataupun gagasan yang terdapat dalam pikirannya untuk menyajikan data tersebut secara tulisan. SA juga mampu menuliskan keterangan pada gambar yang menunjukkan pemahaman tentang keterkaitan dari informasi-informasi yang didapat. Hal ini juga didukung dengan hasil wawancara, yaitu SA mampu menjelaskan dengan jelas maksud gambar yang telah dibuat. Pada indikator ketiga yaitu melakukan perhitungan, SA mampu melakukan perhitungan secara tepat dalam menyelesaikan permasalahan. Perhitungan ditulis secara rinci serta dapat diuraikan dengan benar secara lisan.

Selanjutnya pada indikator keempat yaitu menuliskan simbol dan aturan matematika, hal ini terlihat dari kesesuaian tanda dan simbol-simbol yang digunakan untuk menyelesaikan permasalahan. Dalam menggambar grafik di bidang kartesius maupun menuliskan formula untuk mencari kecepatan, SA cenderung menggunakan variabel $x$ dan $y$. Artinya SA cenderung mengabaikan makna dari pada variabel-variabel yang diketahui pada soal dengan grafik yang dibuat maupun formula yang digunakan. Hal ini juga diungkapkan secara lisan dengan alasan bahwa telah membuat pemisalan pada langkah awal penyelesaian masalah. Selain itu, tipe artisan juga tidak mampu menyatakan unsur yang ditanyakan yaitu kecepatan/luas ke dalam bentuk simbol. SA lebih cenderung menuliskan dan menyebutkan dengan kata-kata. Hal ini sejalan dengan pendapat Keirsey dan Bates (Yuwono, 2010) bahwa dalam berkomunikasi, tipe artisan lebih menyukai menggunakan kata-kata konkrit. Selain itu, tipe artisan juga termasuk dalam kategori komunikator konkrit sehingga cenderung membicarakan sesuatu hal tentang realitas dan menulis secara faktual.

\subsection{Kemampuan Komunikasi Subjek SI Dalam Menyelesaikan Masalah Penerapan Integral Tentu Ditinjau Dari Tipe Kepribadian Idealist}

Dari hasil analisis terhadap hasil pekerjaan dan hasil wawancara SI, pada indikator komunikasi matematis yang pertama yaitu menuliskan hal-hal yang relevan dengan permasalahan, SI mampu menuliskan informasi diketahui secara lengkap dan benar. Sementara untuk informasi yang ditanyakan subjek hanya menuliskan salah satu dari dua yang diperintahkan. Namun dari hasil wawancara SI mampu menjelaskan informasi yang diketahui maupun yang ditanyakan secara singkat dan jelas. SI lebih memilih cenderung fokus dalam rumusan mencari kecepatan sebagai inti dari permasalahan yang diberikan. Hal ini berarti SI telah mampu memahami isi dari permasalahan yang diberikan. Karena tipe idealist merupakan komunikator konkrit, maka tipe ini cenderung mengemukakan sesuatu hal tentang realitas dan menulis secara faktual.

Selain mampu menuliskan informasi yang diketahui maupun ditanyakan dalam soal dengan benar, SI juga mampu menuliskan dan menerapkan formula yang sesuai untuk menyelesaikan masalah. Menurut Keirsey (Librianti, 2018), seseorang yang memiliki tipe kepribadian idealist termasuk dalam kategori cooperatif, yang mana mereka akan memilih jalan umum dalam meyelesaikan masalah. Hal ini terlihat dari upaya SI untuk mencari informasi yang belum lengkap untuk menggambar grafik yang diminta, menggunakan formula sederhana yang dapat dipahami dengan baik oleh orang lain.

Berdasarkan tabel bantu yang digunakan untuk mencari titik-titik koordinat serta diuraikan dengan lancar secara lisan, hal ini menggambarkan bahwa SI cenderung mampu menuliskan maupun mengungkapkan secara lisan tentang suatu penyelesaian secara empiris, sesuai dengan pendapat Keirsey (Librianti, 2018) bahwa tipe idealis merupakan komunikator konkrit yang berbicara dan menulis secara detail, spesifik, empiris, dan faktual.

Selanjutnya, pada indikator komunikasi matematis kedua, SI mampu membuat gambar yang relevan dengan permasalahan. Gambar yang dibuat berupa kurva pada bidang kartesius yang disesuaikan dengan informasi-informasi yang diketahui dan telah dilengkapi. Kemampuan SI dalam membuat gambar yang relevan dengan 
permasalahan ini menunjukkan bahwa SI mampu mengomunikasikan ide ataupun gagasan yang terdapat dalam pikirannya untuk menyajikan data tersebut secara tulisan. Tipe idealist juga mampu menuliskan keterangan pada gambar yang menunjukkan pemahaman tentang keterkaitan antar informasi-informasi yang didapat. Hal ini juga didukung dengan hasil wawancara, yaitu SI mampu menjelaskan dengan lancar dan jelas maksud gambar yang telah dibuat.

Pada indikator ketiga yaitu melakukan perhitungan, SI mampu melakukan perhitungan secara tepat dalam menyelesaikan permasalahan. Perhitungan ditulis secara detail serta dapat diuraikan secara lisan, walau terkadang SI terbatabata. Selanjutnya pada indikator keempat yaitu menuliskan simbol dan aturan matematika, hal ini terlihat dari kesesuaian tanda dan simbol-simbol yang digunakan untuk menyelesaikan permasalahan. Dalam menggambar grafik di bidang kartesius maupun menuliskan formula untuk mencari kecepatan, SI cenderung menggunakan variabel $t$ dan $a$. Artinya SI mampu memahami simbol-simbol yang diketahui pada soal dan mampu menerapkannya sesuai dengan permasalahan. Hal ini juga diungkapkan secara lisan dengan benar. Namun, SI tidak mampu menyatakan unsur yang ditanyakan yaitu kecepatan ke dalam bentuk simbol. SI lebih memilih menulis dan menyebutkannya dengan kata-kata. Selain itu, SI cenderung berfokus pada luas daerah yang dilambangkan dengan $(L)$. Hal ini dikarenakan SI termasuk dalam kategori komunikator abstrak yang lebih memilih menulis dan berbicara tentang ide-ide secara umum (Keirsey dan Bates dalam Yuwono, 2010).

\subsection{Kemampuan Komunikasi Subjek SG Dalam Menyelesaikan Masalah Penerapan Integral Tentu Ditinjau Dari Tipe Kepribadian Guardian}

Dari hasil analisis terhadap hasil pekerjaan dan hasil wawancara SG, pada indikator komunikasi matematis yang pertama yaitu menuliskan hal-hal yang relevan dengan permasalahan, SG hanya mampu menuliskan informasi diketahui secara singkat. SG tidak menuliskan informasi apa saja yang ditanyakan. Hal ini serupa dengan penelitian yang dilakukan oleh Panjaitan (2015) dan Muffarifah, dkk (2016) bahwa tipe guardian cenderung tidak merumuskan hal yang ditanyakan secara tulisan. Namun dari hasil wawancara SG mampu menjelaskan informasi yang diketahui maupun yang ditanyakan secara singkat dan jelas. Hal ini berarti SG telah mampu memahami isi dari permasalahan yang diberikan.
Selain mampu menuliskan informasi yang diketahui maupun ditanyakan dalam soal dengan benar, SG juga mampu menuliskan dan menerapkan formula yang sesuai untuk menyelesaikan masalah. Menurut Keirsey (Librianti, 2018), seseorang yang memiliki tipe kepribadian guardian termasuk dalam kategori cooperatif, yang mana mereka akan memilih jalan umum dalam meyelesaikan masalah. Hal ini terlihat dari upaya SG untuk mencari informasi yang belum lengkap untuk menggambar grafik yang diminta menggunakan formula sederhana yang dapat dipahami dengan baik oleh orang lain.

Selanjutnya, pada indikator komunikasi matematis kedua, SG mampu membuat gambar yang relevan dengan permasalahan. Gambar yang dibuat berupa kurva pada bidang kartesius, namun kurva yang dihasilkan tidak menyerupai kurva parabola yang sempurna. Hal ini dikarenakan SG membuat kurva hanya disesuaikan dengan informasi-informasi yang diketahui, dengan cara menarik garis secara linier dan dihubungkan pada titik-titik koordinat yang diketahui. Artinya SG tidak menyadari bahwa persamaan yang diketahui merupakan persamaan parabola. Pemanfaatan data berdasarkan fakta yang tampak memang merupakan ciri dari tipe ini, karena guardian termasuk dalam tipe sensing yang selalu melihat fakta sebagai acuan dalam menyelesaikan masalah (Keirsey, 1998).

Kemampuan SG dalam membuat gambar yang relevan dengan permasalahan ini menunjukkan bahwa SG mampu mengomunikasikan ide ataupun gagasan yang terdapat dalam pikirannya didasarkan fakta yang ada untuk menyajikan data tersebut secara tulisan. Hal ini juga didukung dengan hasil wawancara, yaitu SG mampu menjelaskan dengan jelas maksud gambar yang telah dibuat. Hal ini dikarenakan SG merupakan komunikator konkrit, maka tipe ini cenderung mengemukakan sesuatu hal tentang realitas dan menulis secara faktual.

Pada indikator ketiga yaitu melakukan perhitungan, SG mampu melakukan perhitungan secara tepat SG dalam menyelesaikan permasalahan. Perhitungan ditulis secara rinci serta dapat diuraikan dengan benar dan lancar secara lisan.

Selanjutnya pada indikator keempat yaitu menuliskan simbol dan aturan matematika, hal ini terlihat dari kesesuaian tanda dan simbol-simbol yang digunakan untuk menyelesaikan permasalahan. Dalam menggambar grafik di bidang kartesius maupun menuliskan formula untuk mencari kecepatan, SG cenderung menggunakan variabel $t$ dan $a$. Artinya SG mampu memahami simbol-simbol yang diketahui 
pada soal dan mampu menerapkannya dengan baik. Hal ini juga diungkapkan secara lisan dengan tepat. Namun, SG tidak mampu menyatakan unsur yang ditanyakan yaitu kecepatan/luas ke dalam bentuk simbol. SG lebih cenderung menuliskan dan menyebutkan dengan kata-kata. Hal ini sejalan dengan pendapat Keirsey dan Bates (Yuwono, 2010) bahwa dalam berkomunikasi, tipe guardian lebih condong menggunakan kata-kata dalam membahas sesuatu hal tentang realitas dan menulis secara faktual.

\subsection{Kemampuan Komunikasi Subjek SR Dalam Menyelesaikan Masalah Penerapan Integral Tentu Ditinjau Dari Tipe Kepribadian Rational}

Dari hasil analisis terhadap hasil pekerjaan dan hasil wawancara SR, pada indikator komunikasi matematis yang pertama yaitu menuliskan hal-hal yang relevan dengan permasalahan, SR mampu menuliskan informasiinformasi yang diketahui dan ditanyakan sesuai dengan soal yang diberikan secara rinci dan jelas. Hal ini diperjelas dengan hasil wawancara yang mana SR mampu menjelaskan informasi yang diketahui maupun yang ditanyakan secara rinci dan jelas. Sesuai dengan pendapat Keirsey (Librianti, 2018) bahwa tipe rational merupakan komunikator abstrak yang cenderung menuliskan serta membicarakan suatu hal secara detail dan faktual. Hal ini juga berarti SR telah mampu memahami isi dari permasalahan yang diberikan.

Selain mampu menuliskan informasi yang diketahui maupun ditanyakan dalam soal dengan lengkap, SR juga mampu menuliskan dan menerapkan formula yang sesuai untuk menyelesaikan masalah. Menurut Keirsey (Librianti, 2018), seseorang yang memiliki tipe kepribadian rational dalam meyelesaikan masalah termasuk dalam kategori utilitarian, yang mana mereka akan memilih cara paling efektif menurut mereka. Hal ini terlihat dari upaya SR untuk mencari informasi yang belum lengkap untuk menggambar grafik yang diminta, dengan menerapkan formula yang menurutnya paling efektif. Namun, walaupun cara yang digunakan terlihat umum dan mampu diterima oleh orang lain, cara yang digunakan masih belum efektif dalam membuat gambar, sehingga akan berpengaruh pada hasil gambar yang diperoleh.

Selanjutnya, pada indikator komunikasi matematis kedua, SR mampu membuat gambar yang relevan dengan permasalahan. Gambar yang dibuat berupa kurva pada bidang kartesius yang disesuaikan dengan informasi-informasi yang diketahui. Kemampuan SR dalam membuat gambar yang relevan dengan permasalahan ini menunjukkan bahwa SR mampu mengomunikasikan ide ataupun gagasan yang terdapat dalam pikirannya sesuai dengan informasi yang diperoleh untuk menyajikan data tersebut secara tulisan. Hal ini juga didukung dengan hasil wawancara, yaitu SR mampu menjelaskan dengan jelas maksud gambar yang telah dibuat. Namun dari hasil gambar yang dibuat, SR merasa kesulitan untuk melihat hubungan atau keterkaitannya dengan masalah menentukan kecepatan dan petunjuk yang diberikan di awal. SR hanya berfokus pada membuat gambar kurva yang tepat dan lengkap.

Pada indikator ketiga yaitu melakukan perhitungan, SR mampu melakukan perhitungan secara tepat dalam menyelesaikan permasalahan. Perhitungan ditulis secara rinci serta dapat diuraikan dengan benar secara lisan walaupun terbata-bata.

Selanjutnya pada indikator keempat yaitu menuliskan simbol dan aturan matematika, hal ini terlihat dari kesesuaian tanda dan simbol-simbol yang digunakan untuk menyelesaikan permasalahan. Dalam menggambar grafik di bidang kartesius, SR cenderung menggunakan variabel $x$ dan $y$. Artinya SR cenderung mengabaikan makna dari pada variabel-variabel yang diketahui pada soal dengan grafik yang dibuat maupun formula yang digunakan. Hal ini diperjelas secara lisan dengan alasan bahwa SR lebih terbiasa dengan menggunakan variabel $x$ dan $y$ dalam menggambar pada bidang kartesius. Selanjutnya, dalam menuliskan formula untuk mencari kecepatan, SR mampu menerapkan simbol $t$ sebagai variabel integrasi. Dan SR mampu menyatakan unsur yang ditanyakan yaitu kecepatan ke dalam bentuk simbol (v). SR lebih cenderung mampu menuliskan dengan kata-kata maupun simbol. Namun dari hasil wawancara, SR sering mengalami kesulitan untuk menyebutkan lambang atau tanda tertetu. Misalnya dalam menyebut satuan percepatan: $\mathrm{m} / \mathrm{s}^{2}$, subjek sering mengalami kesulitan untuk menyatakan secara lisan bahkan salah. $\mathrm{m} / \mathrm{s}^{2}$ ketika dilisankan menjadi "meter per sekon persegi" dan "meter per sekon kubik". Selain itu SR merasa kesulitan saat menyebutkan variabel integrasi yang dinyatakan sebagai lambang integral. Hal ini sesuai dengan ciri khas tipe ini sebagai komunikator utilitarian dan sejalan dengan pendapat Keirsey dan Bates (Yuwono, 2010) bahwa dalam berkomunikasi, tipe rational lebih menyukai berbicara tentang ide-ide dan lebih suka membahas apa yang ada di pikiran mereka daripada apa yang mereka amati.

\section{Kesimpulan}


Berdasarkan hasil analisis data dan pembahasan, dapat diambil kesimpulan tentang kemampuan komunikasi matematis mahasiswa dengan tipe kepribadian artisan, idealist, guardian, dan rational menurut tipe kepribadian Keirsey sebagai berikut. (a) Kemampuan komunikasi matematis tulis mahasiswa Artisan, SA dalam menyelesaikan masalah penerapan integral tentu, memiliki karakteristik yang cenderung menyatakan ide dan gagasannya secara lisan dibandingkan dengan tulisan. Dari empat indikator komunikasi matematis, SA memenuhi tiga indikator yakni mampu menuliskan informasi yang diketahui dan ditanyakan, membuat gambar, dan melakukan perhitungan, sedangkan pada indikator menerapkan simbol matematis SA cenderung kurang mampu memahami dan menerapkan simbol matematis sesuai dengan permasalahan yang dimaksudkan; (b)Kemampuan komunikasi matematis mahasiswa Idealist, SI dalam menyelesaikan masalah penerapan integral tentu, memiliki karakteristik yang cenderung menyatakan ide dan gagasannya secara lisan dibandingkan dengan tulisan. Dari empat indikator komunikasi matematis, SI memenuhi empat indikator yakni mampu menuliskan informasi yang diketahui dan ditanyakan, membuat gambar, melakukan perhitungan, dan menerapkan simbol dan aturan matematis sesuai dengan permasalahan yang dimaksudkan; (c) Kemampuan komunikasi matematis mahasiswa Guardian, SG dalam menyelesaikan masalah penerapan integral tentu, memiliki karakteristik yang cenderung menyatakan ide dan gagasannya secara lisan dibandingkan dengan tulisan. Dari empat indikator komunikasi matematis, SG memenuhi tiga indikator yakni mampu membuat gambar, melakukan perhitungan, dan menuliskan simbol dan aturan matematis. Sedangkan pada indikator menuliskan informasi yang relevan dengan permasalahan, SG cenderung kurang mampu menuliskan secara lengkap; (d) Kemampuan komunikasi matematis mahasiswa Rational, SR dalam menyelesaikan masalah penerapan integral tentu, memiliki karakteristik yang cenderung menyatakan ide dan gagasannya secara tulisan dibandingkan dengan lisan. Dari empat indikator komunikasi matematis, SR memenuhi dua indikator yakni mampu menuliskan informasi yang diketahui dan ditanyakan, dan melakukan perhitungan, sedangkan pada indikator dua lainnya yaitu membuat gambar dan menerapkan simbol matematis, SR cenderung kurang mampu melakukannya sesuai permasalahan yang diberikan.

\section{Daftar Pustaka}

Armiati. 2009. Komunikasi Matematis dan Kecerdasan Emosional. Prosiding Seminar Nasional Matematika dan Pendidikan Matematika Jurusan Pendidikan Matematika FMIPA UNY. HIm. 270-280.

Aziz, A., Kusmayadi, T. A., \& Sujadi, I. (2014). Proses Berpikir Kreatif dalam Pemecahan Masalah Matematika Ditinjau dari Tipe Kepribadian Dimensi Myer-Briggs Siswa Kelas VIII MTs Nw Suralaga Lombok Timur Tahun Pelajaran 2013/2014. Jurnal Elektronik Pembelajaran Matematika ISSN: 2339-1685, 2(10), 10791093.

Dewi, I. 2014. Profil Keakuratan Komunikasi Matematis Mahasiswa Calon Guru Ditinjau dari Perbedaan Jender. Jurusan Matematika Universitas Negeri Medan. Jurnal Didaktik Matematika Vol. 1, No. 2, September 2014. ISSN: 2355-4185.

Dewiyani, S. 2009. Karakteristik Proses Berpikir Siswa Dalam Mempelajari Matematika Berbasis Tipe Kepribadian. Prosiding Seminar Nasional Penelitian, Pendidikan dan Penerapan MIPA Fakultas MIPA, Universitas Negeri Yogyakarta, 16 Mei 2009.

Hodiyanto. 2017. Kemampuan Komunikasi Matematis Dalam Pembelajaran Matematika. Jurnal AdMathEdu Vol 7 No 1.ISSN 2088-687X.

Julita, S., Herawaty, D., \& Gusri, S. (2019). PENGARUH KECERDASAN EMOSIONAL, DAN SELF EFFICACY TERHADAP KINERJA GURU MATEMATIKA. JUPITEK: Jurnal Pendidikan Matematika, 2(1), 31-34. https://doi.org/10.30598/jupitekvol2iss1pp3134

Keirsey, D. 1998. Please Understand Me II Character \& Temperament Types. California: Promentheus Nemesis Book Company.

Khamidah Khusnul \& Suherman, 2016. Proses Berpikir Matematis Siswa dalam Menyelesaikan Masalah Matematika Ditinjau dari Tipe Kepribadian Keirsey. IAIN Raden Intan Lampung. Al-Jabar: Jurnal Pendidikan Matematika Vol. 7, No. 2, 2016, Hal 231 248. P-ISSN 2086-5872, e-ISSN 2540-7562.

Librianti, V.2018. Proses Komunikasi Matematis Siswa SMP Berdasarkan Tipe Kepribadian Keirsey Dalam Menyelesaikan Masalah Terbuka Geometri. Tesis, tidak dipublikasikan. Program Pascasarjana Jember: Jember.

Masrukan, et al. 2015. Analysis of Mathematical Communication Ability Through 4K Model Based on 7th Graders' Personality Types. International Journal of Education and Research Vol. 3 No. 7 July 2015. ISSN: 24115681.

Maya Nis. 2018. Analisis Tipe Kepribadian Siswa Dan Pengaruhnya Terhadap Kemampuan Pemecahan Masalah Matematika 
Menggunakan Model Problem Based Learning. Universitas Pasundan. Jurnal Symmetry. Volume 3 Nomor 1, Juni 2018 ISSN 2548-2297.

Mufarrihah,. dkk. 2016. Kemampuan Komunikasi Matematis Siswa Kelas IX Sekolah Menengah Pertama Dalam Memecahkan Masalah Matematika Berdasarkan Tipe Kepribadian Siswa. Jurnal Elektronik Pembelajaran Matematika. Jurnal Vol.4, No.7, hal 656-667 September 2016, ISSN: 2339-1685.

Musyrifah, E. 2015. Kemampuan Komunikasi Matematika Pada Pembelajaran Kalkulus Melalui Pendekatan Konstekstual. Jakarta: Fakultas Ilmu Tarbiyah dan Keguruan Universitas Islam Negeri Syarif Hidayatullah. Jurnal Edumatica Volume 05 Nomor 01, April 2015. ISSN: 2088-2157

National Council of Theachers of Mathematics (NCTM) . 2000. Principles and Standards for School Mathematics. USA: The National Council of Mathematics, Inc.

Nuraeni, R. \& Luritawaty, I.P. 2016. Mengembangkan Kemampuan Komunikasi Matematik Siswa melalui Strategi Think Talk Write. Jurnal Pendidikan Matematika STKIP Garut. Jurnal Mosharafa Volume 5, Nomor 2, Mei 2016. ISSN 20864280.

Panjaitan Binur. 2015. Karakteristik Metakognisi Siswa Dalam Memecahkan Masalah Matematika Berdasarkan Tipe Kepribadian. Universitas Hkbp Nommensen. Jurnal Ilmu Pendidikan, Jilid 21, Nomor 1, Juni 2015, Hlm. 19-28.

Qohar, A. 2011. Mathematical Communication: What And How To Develop It In Mathematics Learning?. International Seminar and the Fourth National Conference on Mathematics Education 2011. Department of Mathematics Education, Yogyakarta State University. Proceeding ISBN : 978-979-16353-7-0.

Ramdani, M. 2012. Pengembangan Instrumen Dan Bahan Ajar Untuk Meningkatkan Kemampuan Komunikasi, Penalaran, Dan Koneksi Matematis Dalam Konsep Integral. Jurnal Penelitian Pendidikan Vol. 13 No. 1.

Sugiyono. 2013. Memahami Penelitian Kualitatif. CV. Alfabeta. Bandung.

Sumarmo (dkk). 2018. Hard Skills dan Soft Skills Matematik Siswa. Bandung: Refika Aditama

Utaminingsih, S., \& Setyabudi, I. (2012). Tipe Kepribadian dan Prokrastinasi Akademik pada Siswa SMA " X " Tangerang. Jurnal Psikologi Volume, 10(1), 48-57.

Yuwono, A. 2010. Profil Siswa SMA dalam Memecahkan Masalah Matematika ditinjau dari Tipe Kepribadian. Tesis: Program Pascasarjana Pendidikan Matematika Universitas Sebelas Maret Surakarta. 
